\title{
Correction to: "Nonsense Rides Piggyback on Sensible Things": The Past, Present, and Future of Graphology
}

\author{
Deborah Ellen Thorpe
}

\section{Correction to:}

Chapter 9 in: H. C. Tweed, D. G. Scott (eds.), Medical Paratexts from Medieval to Modern, Palgrave Studies in Literature, Science and Medicine, https://doi.org/10.1007/978-3-319-73426-2_9

The chapter "“Nonsense Rides Piggyback on Sensible Things": The Past, Present, and Future of Graphology" has been made Open Access under a CC BY 4.0 license.

The updated online version of this chapter can be found at https://doi.org/10.1007/978-3-319-73426-2_9 